\title{
Andreas NIJENHUIS-BESCHER
}

ORCID: 0000-0001-9786-4494

Hankuk University of Foreign Studies, Seoul, South Korea

\section{De Zonnekoning en de Republiek. De uitbeelding van de Nederlanden in de Spiegelzaal van Versailles*}

\begin{abstract}
Nowadays, Versailles is mainly a tourist attraction, which draws 8.1 million visitors per year (figure 2018, Versailles Annual Activity Report). However, it was built in the second half of the $17^{\text {th }}$ century to serve as the centre of the French monarchy and exemplifies a symbolic vision of the ideal monarchy, according to Louis XIV. The Hall of Mirrors is the focal point of the political representation displaying the French wealth and power of the Grand Siècle. The Franco-Dutch War (1672-1678) is the main subject of the historical decoration, painted by Charles Le Brun. The Dutch Republic is an essential part of the political theory depicted here, and serves as a counter-example to the idealised absolute monarchy embodied by the Sun King himself. Hence, the small Dutch Republic, then in its heyday, is a crucial partner to France in this elegant albeit conflictual pas de deux. The manner of portraying the Republic is significant for the understanding of the royal credo of Louis's France, and emphasises the essential role of the Dutch Republic in $17^{\text {th }}$-century Europe.
\end{abstract}

Keywords: Dutch Republic, French monarchy, absolutism, Louis XIV of France, Versailles, political philosophy, symbolic representation, Franco-Dutch War, Third Anglo-Dutch War, $17^{\text {th }}$ century.

Versailles, Versalia. Het was maar een klein Kasteel, waar Lodewijk XIII Koning van Frankrijk zijn jachtgezelschappen onderbracht [..]. Lodewijk de Grote heeft er een mooie stad laten bouwen met symmetrie en kaarsrechte straten, $\&$ een Paleis waardig om de grote Koning die

* Aan Jan Urbaniak betuig ik mijn hartelijke dank voor de uitnodiging deel te nemen aan dit themanummer. 
het bewoont, \& het meest beleefde, briljante en imposante Hof ter wereld te huisvesten. Dit Paleis $[\ldots]$ overtreft het mooiste en het grootste in het universum $[\ldots]^{1}$

\section{Inleiding: Versailles en de Nederlandse Republiek}

Het kasteel van Versailles, niet ver ten oosten van Parijs, is een van de belang-

Michel-Antoine Baudrand, Dictionnaire géographique et historique, 1705

rijkste paleizen in Frankrijk. Heden ten dage is het voornamelijk een toeristische trekpleister, waar ieder jaar miljoenen toeristen uit de hele wereld zich vergapen aan de pracht en weelde van de classicistische architectuur en de grandioze tuinen. Daarnaast is het ook nog steeds een plek van politiek belang, waar het Franse parlement en de senaat, verenigd in het congres, plechtig bijeenkomen om over constitutionele veranderingen te stemmen.

De plek is al eeuwen beladen met geschiedenis. Na de Eerste Wereldoorlog werd het Verdrag van Versailles er voorbereid en getekend. Vijftig jaar daarvoor, in januari 1871, vonden kanselier Bismarck (1815-1898) en de kersverse Kaiser Wilhelm (1797-1888) het de uitgelezen plaats om de Duitse eenheid af te kondigen, juist omdat Versailles bij uitstek symbool staat voor Frankrijk. Dit was een onbedoeld eerbetoon aan de intenties van de initiatiefnemer van het bouwen van het weergaloze paleis, Lodewijk de Veertiende (1638-1715). De Zonnekoning heeft namelijk drieënhalve eeuw geleden Versailles doelbewust verheven tot een politiek monument, ter meerdere glorie van de Franse monarchie.

In de tweede helft van de zeventiende eeuw werden kosten noch moeite gespaard om het bescheiden jachtpaviljoen dat Lodewijk XIII (1601-1643) had laten bouwen in de wildrijke bossen om te vormen tot het voornaamste decor van de absolutistische monarchie. In mei 1682 streek het Franse hof definitief neer in

1 “Versailles, Versalia. Ce n'étoit qu'un petit Château où Louis XIII. Roi de France tenoit ses équipages de chasse, dans l'Isle de France, à quatre lieuës de Paris vers l'Occident. Louis le Grand y a fait bâtir une belle ville avec simmetrie, \& les ruës tirées au cordeau, \& un Palais digne de loger le grand Roi qui l'habite, \& la Cour du monde la plus polie, la plus brillante, \& la plus auguste. Ce Palais $[\ldots]$ surpasse tout ce qu'il y a de plus beau $\&$ de plus grand dans l'univers, tant pour son architecture $\&$ ses richesses que pour la multitude de peintures \& de sculptures anciennes \& modernes". Michel-Antoine Baudrand, Dictionnaire géographique et historique, Parijs: Florentin Delaulne, 1705, deel 2, p. 1835. Vergelijk Piganiol de la Force, Description des châteaux et parcs de Versailles, de Trianon, et de Marly, Amsterdam: David Mortier, 1715, deel I, p. 2, die deze passage bijna letterlijk overneemt: "Quand Versailles devint l'objet des soins de Sa Majesté, ce n'étoit qu'un petit Château où Louis XIII avoit tenu ses équipages de Chasse, au lieu que c'est aujourd'hui un Palais digne de loger le grand Roi qui l'habite, \& la Cour du monde la plus brillante \& la plus auguste". 
Versailles, en maakte zo van het ornamentele kasteel het politieke centrum van Frankrijk, en daarmee een van de belangrijkste centra van Europa. De bouw zou decennia duren, duizenden arbeiders bezig houden en een resultaat van ongekende grandeur opleveren.

Nederland speelt een opmerkelijke rol in dit staaltje totaalkunst. Men zou verwachten dat zonder uitzondering alles Frans zou zijn in dit paleis dat Frankrijk belichaamt. Qua stijl (Frans classicisme) en bouwmaterialen (systematisch afkomstig uit Frankrijk) is dit inderdaad het geval. Maar juist in het hart van het gebouw, de Spiegelzaal, waar het monarchistische credo van Lodewijk de Veertiende magistraal wordt verbeeld dankzij het penseel van hofschilder Charles Le Brun (1619-1690), is de Republiek der Zeven Provinciën prominent aanwezig, in de vorm van de toen alom bekende Nederlandse Maagd. De Frans-Nederlandse Oorlog (Guerre de Hollande, 1672-1678) vormt het hoofdonderwerp van de iconografische cyclus die het immense plafond van de Grote Galerij versiert. De beeldvorming van de Franse monarchie en de Nederlandse Republiek zijn hier nauw vervlecht, en de Nederlanden fungeren als spiegelbeeld van Lodewijks Frankrijk.

Een aantal historici heeft zich geïnteresseerd voor de manier waarop Lodewijk XIV zijn imago actief heeft willen beïnvloeden, met name middels het gebruik van de kunsten, maar de manier waarop de vergelijking met een buitenlandse mogendheid daartoe gebruikt werd, bleef vooralsnog onderbelicht. ${ }^{2}$ In Nederland maakt het onderzoek naar de zelfkarakterisering ook dankbaar gebruik van de vergelijking van het zelfbeeld en dat van de ander, in navolging van Joep Leerssen en diens imagologie (Manfred \& Leerssen 2007; en het fundamentele Leerssen 1999). Hier wordt echter voornamelijk gewerkt vanuit een Nederlands perspectief, en komt de Nederlandse identiteit uit de verf als een spiegelbeeld van eerst de Spaanse, en vervolgens de Franse 'tirannie'. Deze tekst volgt een omgekeerde blik, en analyseert de manier waarop in Frankrijk het imago van de Republiek wordt geïnstrumentaliseerd om Lodewijk de Veertiende te verheerlijken.

\section{Versailles als centrum van de Franse monarchie}

Het paleis van Versailles is zonder twijfel het meest tastbare overblijfsel van de regeerperiode van Lodewijk XIV, en daarmee van de Franse Grand Siècle. Het besluit om het koninklijke hof op een vaste plaats te huisvesten was een behendig antwoord op de politieke onrust van de Fronde (1648-1653). De nachtelijke vlucht, in januari 1649, van de koninklijke familie uit het opstandige Parijs was zeker een markant moment in de prille jeugd van Lodewijk XIV. Door de Franse adel buiten Parijs en ver van hun eigen bezittingen aan het hof bijeen te brengen

2 Zie bijvoorbeeld het klassieke werk van Apostolidès 1981; Burke 1992; Sabatier 1999. Meer specifiek gewijd aan de manier waarop de Nederlanden verbeeld worden zijn mijn eigen publicaties, waar ik voor deze tekst gebruik van heb gemaakt: Nijenhuis 2001: 75-98; Nijenhuis 2006: 293-321. 
en te onderwerpen aan een strenge etiquette vergrootte de Franse koning zijn greep op deze politiek belangrijke - en soms opstandige - groep.

Dat de keuze van de plek viel op het bescheiden jachtslot van zijn vader, de Bourbon Lodewijk XIII, heeft ongetwijfeld te maken met de wil van de jonge Zonnekoning om een stempel te drukken op de Franse monarchie. Meer dan de paleizen van Fontainebleau of Saint-Germain-en-Laye, sterk verbonden aan de Valois Frans I (1494-1547), bood Versailles de gelegenheid om met een schone lei te beginnen. Vanaf het begin van zijn persoonlijke regering in 1661 en tot aan de dood van de Zonnekoning een halve eeuw later wordt er gewerkt aan het verbouwen van het paleis tot symbool van de ideale monarchie. Louis Le Vau (1612-1670) en zijn opvolgers François d'Orbay (1634-1697) en, vooral, Jules Hardouin-Mansart (1646-1708) en André Le Nôtre (1613-1700) hebben, onder nauw toezicht van de Zonnekoning, gewerkt aan de gebouwen en tuinen die het archetype van een koninklijk hof zijn geworden. In heel Europa verrezen prinselijke hoven naar model van het Franse lustoord. In Nederland is de inspiratie van Versailles terug te vinden in het eind zeventiende-eeuwse paleis Het Loo, gebouwd ten tijde van Willem III (1650-1702), en de Pruisische koning Frederik de Grote (1712-1786) bouwde halverwege de achttiende eeuw met slot Sans Souci zijn antwoord op de creatie van Lodewijk de Grote.

De Grote Galerij, gesitueerd in het midden van de monumentale gevel, die zich over 580 meter uitstrekt tegenover de tuinen, is het onbetwiste centrum van het paleis. De Grote Galerij verdient zijn naam aan de indrukwekkende afmetingen ( 73 meter lang, bijna 11 breed en 13 hoog), en werd in 1678 gebouwd ter vervanging van een italianiserend dakterras dat zich tussen de appartementen van de koning en de koningin bevond. Aan de westkant kijkt de Galerij met zeventien vensters uit op het park, en bevindt zich in de centrale as van het grand canal. Symmetrisch tegenover de grote boogramen bevinden zich zeventien nissen, bekleed met de 357 spiegels die de Galerij algemeen bekend maken als de Spiegelzaal (afbeelding 1).

Door de centrale ligging in het paleis vervult de immense ruimte meerdere rollen: verbinding tussen de twee koninklijke appartementen, wachtruimte, maar ook feest- en zelfs troonzaal tijdens belangrijke ontvangsten. Als ware 'voorkamer' van de Franse monarchie, moest deze galerij allicht een passend decor krijgen. Nadat in 1680 de beeldhouwers hun werk hadden afgerond, kon hofschilder Le Brun tussen 1681 en 1684 de magistrale schilderijen maken die het voornaamste narratief verbeelden. Het thema van de cyclus was zorgvuldig bepaald. In eerste instantie werd er gedacht aan een cyclus met als thema Apollo, de Griekse godheid van het beschavende licht die sterk verbonden is aan het embleem dat de Zonnekoning gekozen had. Omdat Filips van Orléans (1640-1701) dit thema al had gebruikt voor de galerij in zijn paleis van te Saint-Cloud, in 1677 geschilderd door de rivaal van Le Brun, Pierre Mignard (1612-1695), kwam dit idee te 
vervallen. Le Brun had zelf het onderwerp ook al gebruikt in de net opgeleverde Apollo-galerij van het Louvre. Een tweede project, eveneens van mythologische aard, werd gepresenteerd in 1678, en had Hercules tot onderwerp. De symboliek van de onoverwinnelijke kracht van Hercules was weliswaar passend in deze tijden van oorlog, maar Hendrik de Vierde had ook al uitgebreid gebruik gemaakt van deze thematiek.

Het uiteindelijke ontwerp was op verschillende punten vernieuwend. Het kwam kort na het tekenen van de Vrede van Nijmegen (augustus 1678) tot stand. In tegenstelling tot wat sinds de Renaissance gebruikelijk was, werd er gekozen om niet alleen een beroep te doen op mythologische en allegorische schilderingen, maar om de Franse koning zelf te ensceneren. De zojuist afgelopen Frans-Nederlandse Oorlog (1672-1678) kon zo dienen als onderwerp en Lodewijk XIV tonen als heroïsche oorlogsleider. Deze optie was ongekend voor een plafondschildering, en ook de beslissing om de begeleidende teksten in het Frans (in plaats van het gebruikelijke latijn) op te stellen was een duidelijk teken van moderniteit.

De politieke strekking van de iconografische cyclus van de Grote Galerij is dientengevolge explicieter dan de mythologische decors elders in Versailles. Lodewijk de Grote is hier persoonlijk te aanschouwen, en staat op gelijke voet met godheden uit de Oudheid, die, samen met een heel scala aan zinnebeelden en allegorieën, de toentertijd gebruikelijke narratieve referenties vormen. ${ }^{3}$ Aldus zijn de daden van de koning, vanaf het begin van zijn persoonlijke regering tot het sluiten van de Vrede van Nijmegen het onderwerp van de decors, en vormen een justificatie van zijn beleid. De Zonnekoning is aldus de centrale figuur van dit "somptueuze stripverhaal" (Sabatier 1999: 237).

Het hele Franse hof heeft in de Grote Galerij permanent Lodewijk XIV voor ogen, in persoon en in beeld. Dit geldt ook voor buitenlandse bezoekers en delegaties. Voor het binnen- en buitenlandse publiek dat zelf Versailles niet kan aanschouwen, zijn er gedrukte beschrijvingen en etsen die de glorie van de Zonnekonings creatie in heel Europa uitbazuinen. ${ }^{4}$

3 De "iconologische" theorieën van Cesare Ripa (1555-1622) hebben een grote invloed in heel Europa. Zijn Iconologia overo descrittione dell' imagini universali, Rome: Giovanni Gigliotti, 1593, is een ware catalogus van symbolen. Het werk wordt in 1644 zowel in het Frans als in het Nederlands vertaald en uitgegeven. Frijhoff \& Spies (2004: 452-455) stippen zijn invloed op de zeventiende eeuwse schilderkunst aan.

${ }^{4}$ De Franse krant Mercure Galant (vrijwel een regeringsorgaan) wijdt in december 1684 een uitgebreide beschrijving aan de schilderijen van de spiegelzaal. De numismaticus Pierre Rainssant (ca. 1640-1689) publiceert in 1686 zijn Explication des tableaux de la Galerie de Versailles, Versailles, 1686. Ook het lid van de Académie Française François Charpentier (1620-1702) schrijft een tekst ter ere van de iconografische cyclus, onder de titel Traité de la peinture parlante, Explication des tableaux de la Galerie de Versailles, Parijs 1684. De Description sommaire du château de Versailles van de architect André Félibien des Avaux (1619-1695) verschijnt in 1674 in Parijs en in een bijgewerkte vorm in 1696. Ten slotte beleeft ook de beschrijving door Piganiol de la Force een aantal herdrukken tot diep in de $18^{\mathrm{e}}$ eeuw: Piganiol de la Force, Description des châteaux et parcs de 


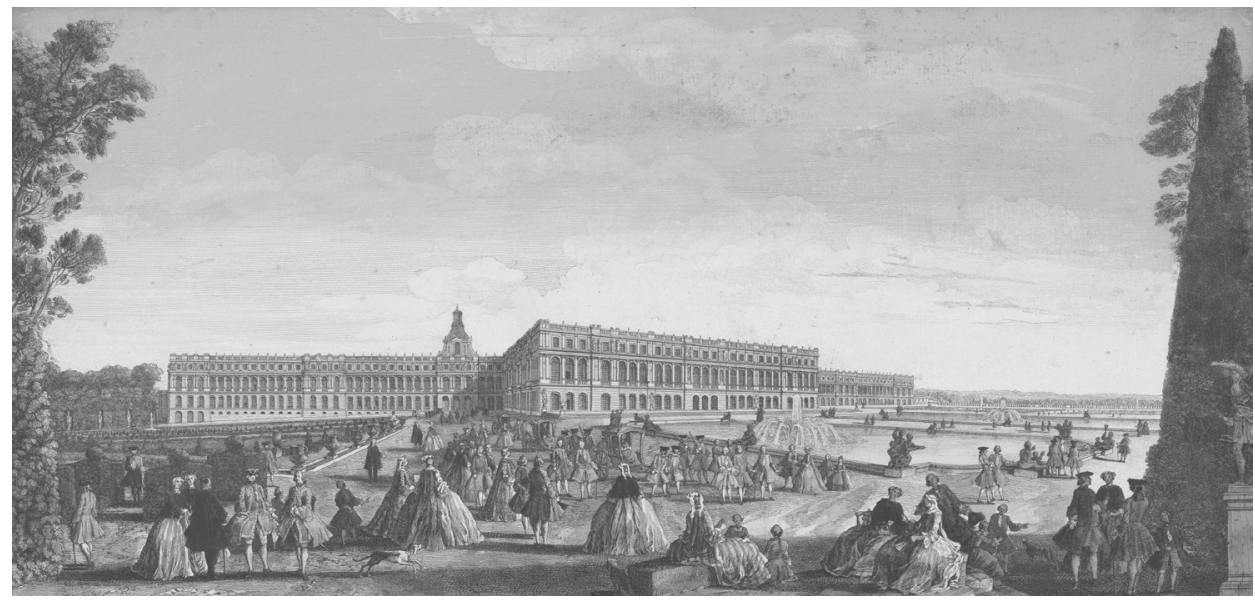

Afbeelding 1. Gezicht op het Paleis van Versailles. Ingekleurde ets, waarschijnlijk door Jacques Rigaud (1680-1754); bron: Rijksmuseum, Amsterdam (RP-P-1980-389)

\subsection{De heroïsche koning}

De Galerij wordt aan weerszijden geflankeerd door twee salons. De Oorlogssalon (Salon de la Guerre) bevindt zich aan de noordzijde en vormt de entree. In het zuiden, dat wil zeggen de kant van het statie-appartement van de koning, sluit de Vredessalon (Salon de la Paix) de cyclus af. Volgens de beoogde manier van ontdekken van de Galerij loopt men zo van de oorlog naar het licht, de koning en de vrede.

Het decor van de Spiegelzaal zelf bestaat uit drie verschillende series schilderijen. Op de middellijn van het gewelfde plafond bevinden zich zes octogonen met een vergulde achtergrond, die fungeren als medaillons. Twaalf kleinere ovale schilderijen omgeven de zeven grote composities. De grote schilderijen bestaan uit vier aparte scènes en drie diptieken, die elk weer uit twee onderling verbonden afbeeldingen bestaan. Samen vormen de grote composities tien taferelen. Boven de gewelfde in- en uitgangen bevinden zich ten slotte nog twee halfcirkelvormige schilderijen, die het verband leggen met de oorlogs- en vredessalons (zie schema, afbeelding 2). Het geheel verhaalt, voor de tijdgenoten die het meegemaakt hebben, maar ook voor het nageslacht, de Frans-Nederlandse oorlog en zijn historische context. Dit alles weliswaar vanuit het zeer Franse en absolutistische perspectief van de opdrachtgever.

Versailles, de Trianon, et de Marly, Amsterdam, David Mortier, 1715 (heruitgegeven in 1722). In het midden van de achttiende eeuw, maakte Jean-Baptiste Massé (1687-1767) een serie gravures van de Galerij en de twee Salons, uitgegeven als La Grande Galerie de Versailles et les deux Salons qui l'accompagnent, peints par Charles Le Brun premier peintre de Louis XIV, dessinés par Jean-Baptiste Massé, Parijs: Veuve Amaulry, 1753. 
De variëteit in vormen, afmetingen en plaatsing op het plafond bieden drie verschillende leesniveaus. Het diptiek in het centrum van de zaal vormt, samen met de omringende vier ovalen en twee achthoeken, het beginpunt van het narratief. Dit ensemble verbeeldt het begin van de regeerperiode van de Zonnekoning, evenals de context van de Frans-Hollandse oorlog. De vier ovalen tonen de persoonlijke kwaliteiten van de koning, via zijn daden in belangrijke binnenlandse domeinen: handel en financiën, justitie en de kunsten (ovalen V tot en met IX). De twee octogonale medaillons hebben betrekking op de Devolutieoorlog (16671668), en vormen een verantwoording voor het hoofdonderwerp van de cyclus (achthoeken C en D). Deze eerste oorlog die door het Frankrijk van Lodewijk XIV gevochten werd, wordt gepresenteerd als een verdediging van de rechten van de Franse koningin, Maria Theresia (1638-1683, koningin van Frankrijk sinds 1660). De oorlog was een militair succes voor Frankrijk, dat op Spanje de Franche-Comté en grote delen van de Zuidelijke Nederlanden veroverde. Door toedoen van de in januari 1668 op Nederlands initiatief gesloten Triple Alliantie tussen de Verenigde Nederlanden, Engeland en Zweden werd Frankrijk echter gedwongen om een groot deel van de veroverde gebieden te restitueren aan Spanje, hetgeen geschiedde met de Vrede van Aken (mei 1668).

Het centrale tweeluik geeft het begin van de regering van Lodewijk XIV weer, en de houding van de andere Europese staten (schilderijen 6 en 7). Geplaatst in het centrum van de Spiegelzaal, tussen de Salon van de Oorlog en die van de Vrede, wordt de Zonnekoning afgebeeld als de scheidsrechter van oorlog en vrede in Europa. Volgens de christelijke opvatting van zijn tijd, bewaart hij de vrede indien mogelijk, en verklaart hij alleen oorlog indien dit noodzakelijk en legitiem is.

De grootte van de schilderijen vormt een tweede interpretatieniveau. De grote taferelen zijn allicht het best zichtbaar vanaf de parketvloer, die zich op meer dan twaalf meter onder het plafond bevindt. De forse panelen vormen daarom de ruggengraat van de vertelling, die aangevuld wordt door de kleinere achthoeken en ovalen. De graad van detaillering hangt hierdoor af van de tijd die het publiek kan besteden aan het ontcijferen van de afbeeldingen. Dit strookt goed met de verschillende functies van de zaal, en de inherente variaties van de tijd die een bezoeker er door kan brengen.

Het semantische systeem berust eveneens op de morfologische verschillen tussen de schilderijen. Het discours verschilt volgens de vorm van de afbeeldingen, die onderverdeeld zijn in drie typen. De octogonen geven de persoonlijke kwaliteiten van de koning weer: gulheid, eerlijkheid, trouw, edelheid, en katholieke vroomheid. Die karakteristieken blijken uit de vaderlijke zorg waarmee hij zijn onderdanen omringt (octogonen A, B, E en F). Deze goudkleurige medaillons hebben voornamelijk betrekking op de binnenlandse politiek, terwijl de ovale taferelen de rang van Frankrijk in Europa betreffen. Uit de twaalf ovalen blijkt dat Lodewijk de Grote in de eerste vijftien jaar van zijn regeren de preëminentie in 
Europa van Spanje overgenomen heeft. Frankrijk snelt er, onder meer, Nederland te hulp tegen Munster (1665, ovaal I), verdedigt Europa tegen de Turken (1664, ovaal III) en ontvangt ambassades uit de hele wereld.

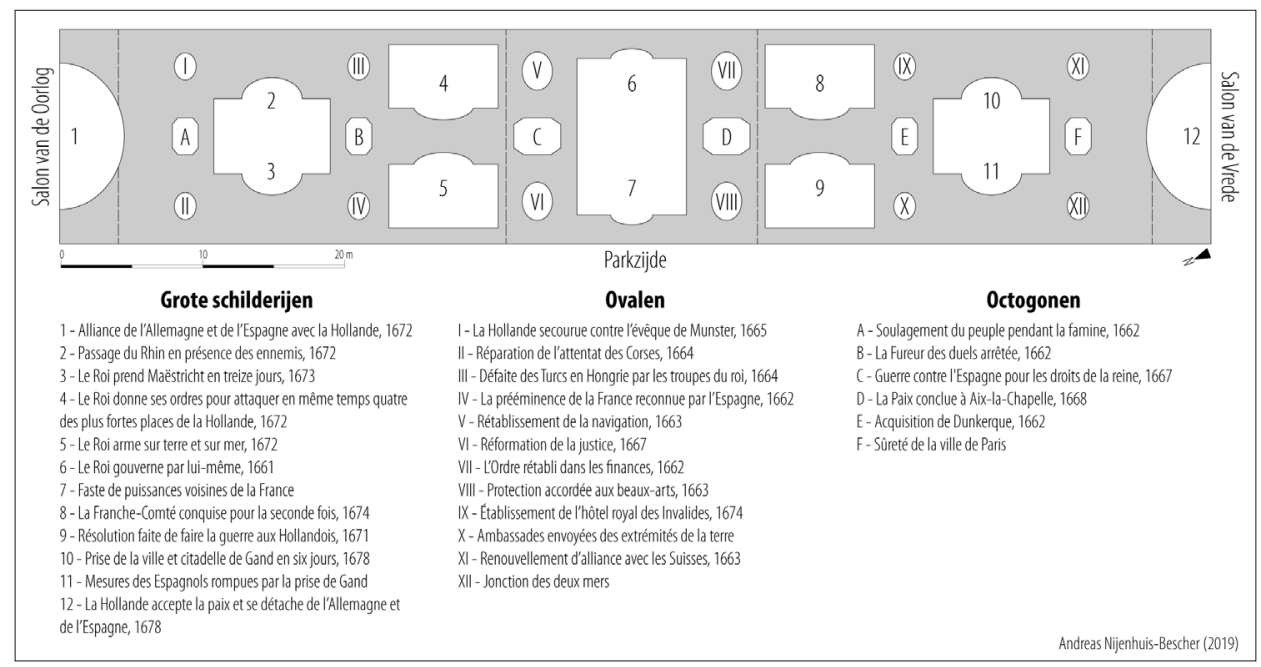

Afbeelding 2. Overzicht van de schilderijen van de Grote Galerij van Versailles. De referenties tussen haakjes in de tekst verwijzen naar dit overzicht. Schema op schaal vervaardigd door Andreas Nijenhuis-Bescher

\section{De 'Hollandse Oorlog' in de Spiegelzaal}

De verhaallijn van de cyclus is het duidelijkst aanwezig in de grote panelen, die, weliswaar niet lineair, de recente gebeurtenissen van de Guerre de Hollande uiteenzetten. De Frans-Nederlandse oorlog brengt een definitieve breuk teweeg tussen de Nederlandse Republiek en Frankrijk. Beide landen hadden sinds het eind van de 16e eeuw een hechte band, voor een deel gemotiveerd door de strijd tegen een gemeenschappelijke vijand, Spanje. Tijdens de Opstand (1568-1648) en de Franse fase van de Dertigjarige Oorlog (1635-1648), werkten de twee landen nauw samen, en sloten meerdere verbonden $(1596,1635)$. Na de Vrede van Westfalen wordt deze alliantie weliswaar verlengd (1662), maar de belangen van beide Europese grootmachten lopen voortaan steeds verder uiteen. ${ }^{5}$

5 Voor een boeiende voorstelling van het ontstaan van Nederland tijdens de Opstand, leze men Van der Lem, Anton, De Opstand in de Nederlanden, 1568-1648. De Tachtigjarige Oorlog in woord en beeld, Nijmegen: Vantilt, 2014. Een algemene geschiedenis van vroegmodern Nederland is het klassieke werk Israel 1995. Allain, Thierry, \& Andreas Nijenhuis-Bescher, Romain Thomas, Les Provinces-Unies à l'époque moderne. De la Révolte à la République batave, Parijs: Armand Colin, 2019. 
De mercantilistische politiek die Jean-Baptiste Colbert (1619-1683) vanaf het begin van de jaren 1660 in de praktijk brengt, maken de Republiek tot een directe concurrent. De douanetarieven van 1661 zijn zeer ongunstig voor de Nederlandse handel, en wekken wrevel in de Republiek. De geopolitieke omslag in de verhoudingen ligt tijdens de Devolutieoorlog. De Franse poging om de Zuidelijke Nederlanden in te lijven, wekken veel argwaan in de Verenigde Provinciën. Men wil het machtige Frankrijk wel te vriend houden, maar niet als directe buur hebben. De Triple Alliantie, gesloten door Nederlands toedoen, slaagt er in 1668 de Franse ambities vooralsnog te temmen, maar besluit Frankrijk ertoe om de Nederlandse macht en welvaart, toen op hun hoogtepunt, te breken.

Lodewijk XIV zoekt daarom toenadering tot Engeland, om een einde te maken aan de Triple Alliantie en de Republiek politiek te isoleren. Met het Geheime Verdrag van Dover (juni 1670), lukt het Frankrijk Karel II van Engeland (1630-1685) te interesseren voor een gezamenlijke aanval op de Nederlanden. De prins-bisschoppen van Keulen en Münster maken eveneens deel uit van het bondgenootschap dat af moet rekenen met de Republiek. Dat is het doel van de Frans-Nederlandse oorlog, die samenvalt met de Derde Engelse Zeeoorlog (1672-1674).

Het 'rampjaar' 1672 is in Nederland algemeen bekend als een moment van ongekende crisis, en volgens het gezegde is de regering dan radeloos, het volk redeloos en het land reddeloos. Vanaf juni 1672 wordt de Republiek van alle kanten aangevallen. Het leger van Lodewijk XIV, dat zijn kunnen al in de Devolutieoorlog had bewezen, rukt op langs zowel de Maas als de Rijn en valt Nederland binnen op 12 juni. In de weken die volgen, valt een veertigtal steden in Franse handen. De Hollandse waterlinie beschermt weliswaar Amsterdam, en daarmee het economische hart van de Republiek, maar de Franse opmars lijkt onstuitbaar. Intussen trekt het leger van de bisschop van Münster 'Bommen Berend' (Bernhard von Galen, 1606-1678) het noorden binnen, verovert Coevorden en slaat het beleg voor Groningen. De Engels-Franse vloot bereidt bovendien de invasie van de kust van Holland voor, die de genadeslag moet brengen (zie kaart, afbeelding 3).

De situatie lijkt dan hopeloos, en op 29 juni doen de Staten Generaal een vredesvoorstel, bestaande uit een grote afkoopsom, maar ook de cessie van de Generaliteitslanden aan Frankrijk. De Zonnekoning rekent echter op de aanstaande invasie van Holland en vergt bovendien de invoering van godsdienstvrijheid voor de katholieken in de Republiek. Deze eis is teveel gevraagd voor de Nederlandse Republiek, die ontstaan is in een lange godsdienstoorlog en waar de calvinistische Publieke Kerk de enige in de publieke ruimte toegestane religie vertegenwoordigt. Verder dan de sinds de Unie van Utrecht (1579) al toegekende gewetensvrijheid willen de Nederlandse regenten niet gaan, en de oorlog woedt daarom verder. 
Het land is inmiddels op de rand van een burgeroorlog beland, en de emblematische staatsgezinde leider tijdens het Eerste Stadhouderloze Tijdperk (1650-1672), Johan de Witt (1625-1672), wordt samen met zijn broeder Cornelis (1623-1672) op 20 augustus 1672 in Den Haag vermoord door een Oranjegezinde menigte. De prins van Oranje Willem III is voortaan onbetwist de politieke en militaire leider van de Republiek. Tijdens deze politieke en militaire crisis biedt de Nederlandse vloot onder leiding van Michiel de Ruyter (1607-1676) succesvol weerstand aan de gecombineerde Frans-Engelse marine. ${ }^{6}$ In vier confrontaties tussen juni 1672 en augustus 1673 slaagt De Ruyter erin om de bedreiging op zee af te slaan.

Op het landfront lukt het Willem III in november 1673, met hulp van de Duitse bondgenoten, om de Franse aanvoerlijnen af te snijden door Bonn in te nemen en zo de Rijn te beheersen. Lodewijk XIV, die vier van de zeven provinciën bezette en zijn hoofdkwartier in Utrecht had ingericht (en daar tot juli 1672 zelf verbleef), besluit daarop om zijn leger uit de Nederlanden terug te trekken. De aftocht vindt plaats tussen eind 1673 en de zomer van 1674. Alleen Maastricht, ingenomen na een spectaculair beleg in juni 1673, blijft nog in Franse handen.

In augustus 1672 breekt de bisschop van Munster het beleg van Groningen op (het Gronings Ontzet wordt nog steeds jaarlijks gevierd op 28 augustus) en de bisschop van Keulen wordt in 1673 gedwongen vrede te sluiten door de Nederlandse inval in het Rijngebied. De belangrijkste Franse bondgenoot laat het eveneens afweten. Vanwege de tegenslagen op zee en een groeiende weerzin om tegen een protestants land te vechten, weigert het Engelse parlement namelijk in november 1673 om nog meer fondsen beschikbaar te stellen voor de oorlog. Al in februari 1674 tekenen Engeland en de Republiek daarom te Westminster een vrede, die een einde maakt aan de Derde Engelse Zeeoorlog. Frankrijk staat er vanaf nu bijna alleen voor. ${ }^{7}$

De oorlog wordt duidelijk een Europese aangelegenheid met het sluiten van de Alliantie van Den Haag (of Quadruple Alliantie, augustus 1673) tussen de Republiek, Keizer Leopold I (1640-1705), de hertog van Lotharingen, en Spanje. De oorlogsvoering verplaatst zich buiten Nederland, met name in de Zuidelijke Nederlanden en de Franche-Comté. Deze Spaanse bezitting wordt in 1674 opnieuw door Frankrijk veroverd, ten koste van een hevige strijd en een moeilijk beleg van Besançon. Verschillende invallen in de Spaanse Nederlanden bepalen de rest van de oorlog, met de veldslagen bij Seneffe (1674), Cassel (1677) en ten slotte de inname van Gent door Franse troepen (1678).

${ }^{6}$ Michiel Adriaensz de Ruyter (1607-1676) behaalt overwinningen in de zeeslagen van Solebay (7 juni 1672), Schooneveld (7 en 14 juni 1673) en Kijkduin (bij Texel, 21 augustus 1673) en verijdelt de landingspogingen.

7 Zweden maakte eveneens deel uit van de Franse alliantie, maar viel de Nederlandse Republiek niet rechtsreeks aan. Zweden raakte voornamelijk slaags met de Nederlandse bondgenoot Brandenburg, in de Schoonse Oorlog (1674-1679). 


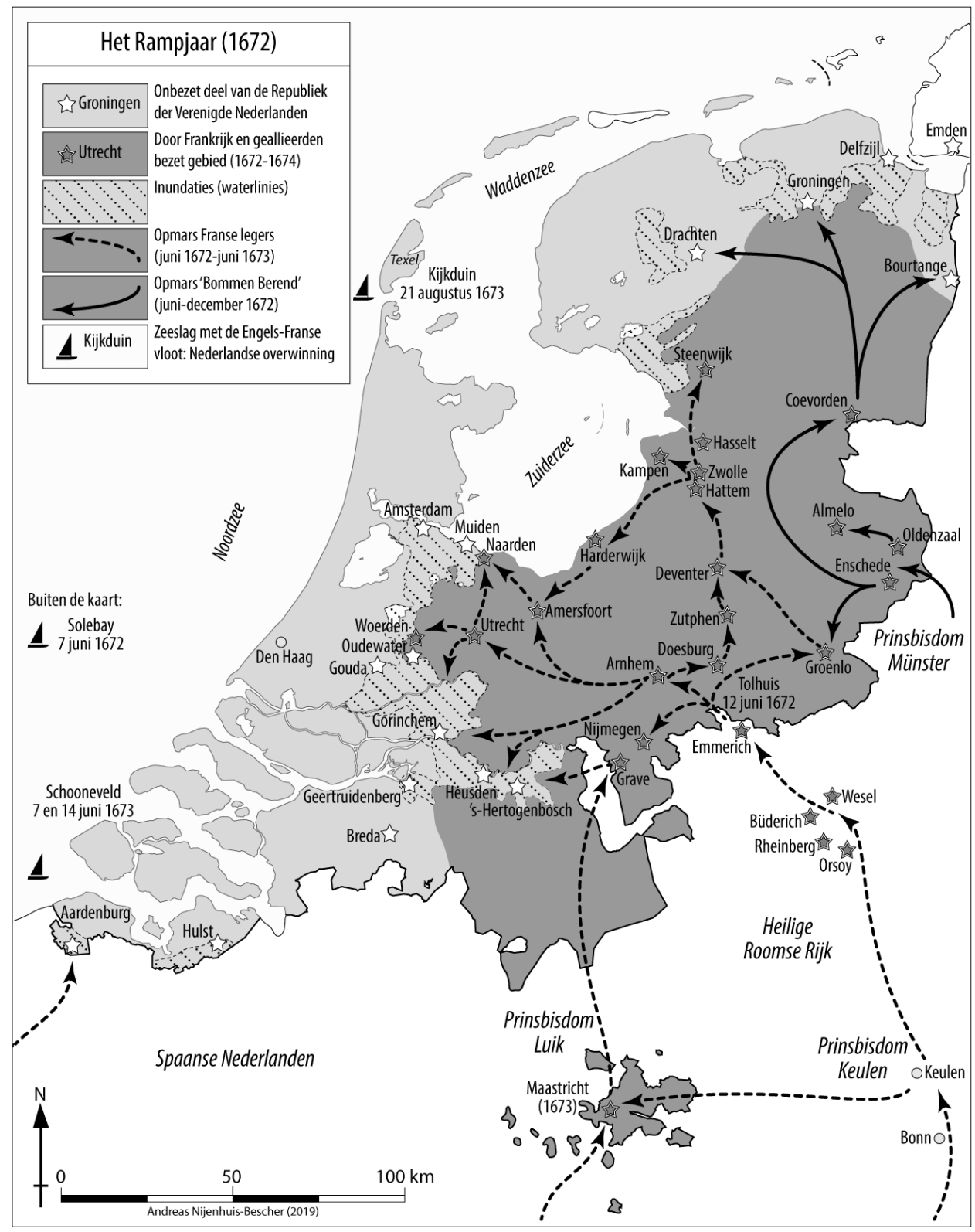

Afbeelding 3. Het Rampjaar (1672). Cartografie: Andreas Nijenhuis-Bescher

$\mathrm{Na}$ zes jaar intensieve oorlogsvoering blijft een definitieve overwinning voor beide partijen uit zicht en wordt er eindelijk ernst gemaakt met vredeson- 
derhandelingen. In 1678 beëindigt Vrede van Nijmegen de strijd. ${ }^{8} \mathrm{Na}$ een benard begin, heeft de Nederlandse Republiek de oorlog overleefd zonder territoriale verliezen en is er in geslaagd het hoofd te bieden aan Lodewijk XIV. Frankrijk boekt weliswaar terreinwinst ten koste van de Spaanse Nederlanden en lijft de steden Valenciennes (Valencijn), Cambrai (Kamerijk), en Maubeuge (Mabuse) in, evenals de Franche-Comté, maar moet voortaan rekenen met een Paneuropese anti-Franse alliantie. Die wordt aangevoerd door de prins van Oranje Willem III en de komende oorlogen (Negenjarige Oorlog en Spaanse Successieoorlog) worden steeds langer en moeilijker voor Frankrijk, vooral vanaf het moment dat stadhouder Willem III eveneens koning van Engeland wordt dankzij zijn geslaagde invasie van Engeland in 1688-1689 (Glorious Revolution). Wanneer de Zonnekoning in september 1715 sterft, heeft hij veel van zijn glans verloren en is Frankrijk uitgeput.

\subsection{Lodewijk de Grote als personificatie van Frankrijk}

De manier waarop de Frans-Nederlandse Oorlog in de schilderijen in Versailles wordt verbeeld is allicht niet puur historisch. Het grote tweeluik in het centrum van de Spiegelzaal zet de toon. Het relaas begint in 1661, toen Lodewijk XIV tegen ieders verwachting in besloot na de dood van kardinaal Mazarin (16021661) geen nieuwe eerste minister meer te benoemen, maar zelf het roer van Frankrijk in handen te nemen (schilderij 6). Een jonge Lodewijk zit op zijn troon, omgeven door de Gratiën. Naast hem zit Frankrijk, die leunt op een schild dat de Onenigheid (verwijzing naar de Fronde) verpletterd. De putti op de voorgrond symboliseren de jeugd van Lodewijk XIV, met zowel vermaak als een gedegen opleiding.

De boodschapper Mercurius legt het verband met het andere gedeelte van het centrale tweeluik. Onder toeziend oog van Apollo, Jupiter en Juno brengt hij het nieuws van de goede regering aan de buurlanden van Frankrijk. De oorspronkelijke titel Trots van de buurlanden van Frankrijk (later vervangen door "weelde") geeft de atmosfeer goed weer (schilderij 7, afbeelding 4). In een driehoekige compositie zitten de allegorieën van Het Heilige Roomse Rijk, Spanje en de Nederlanden trots en welbewust - zo niet arrogant - op de symbolen van hun respectievelijke machten: koloniale ambitie voor Spanje en zeehandel voor de Republiek.

$\mathrm{Na}$ deze contextuele inleiding, begint het eigenlijke verhaal van de Frans-Nederlandse Oorlog. De allegorie van Frankrijk verdwijnt uit beeld, en de koning

${ }^{8}$ De Vrede van Nijmegen bestaat uit drie verschillende traktaten. Op 10 augustus 1678 wordt de vrede getekend tussen Frankrijk en de verenigde Nederlanden, op 17 september de vrede met Spanje, en op 5 februari 1679, tenslotte, de vrede met het Heilige Roomse Rijk. In de Spiegelzaal wordt er zonder onderscheid verwezen naar Duitsland (in feite Brandenburg, bondgenoot van de Republiek) en het Heilige Roomse Rijk. 


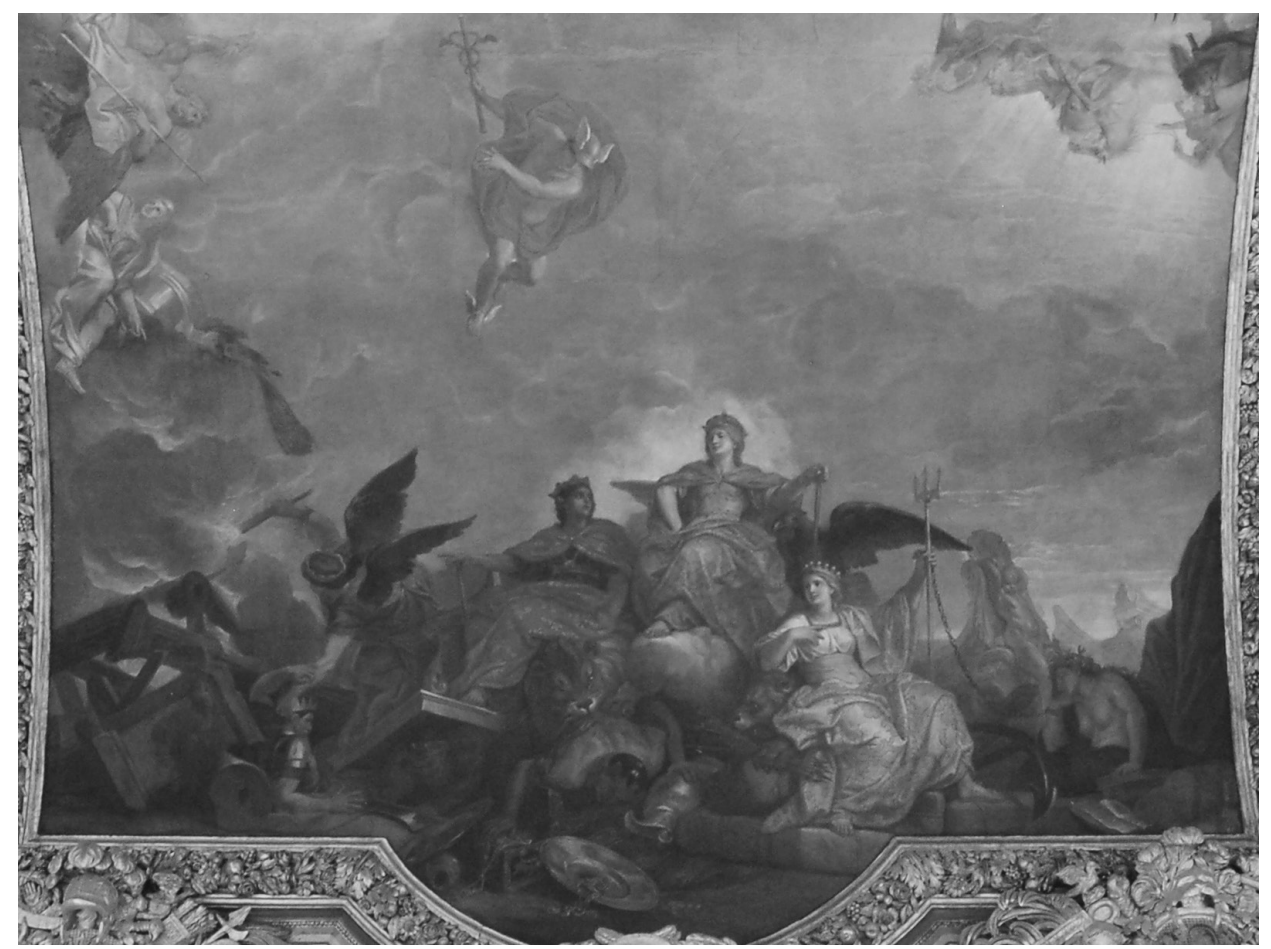

Afbeelding 4. Trots van de buurlanden van Frankrijk (compositie 7); Cliché Andreas Nijenhuis-Bescher

personifieert voortaan hoogstpersoonlijk het land en draagt vanaf nu de blauwe mantel met witte lelies die het land symboliseert. Hij zit in het midden van het schilderij met de titel "Beslissing genomen om de Hollanders de oorlog te verklaren, 1671", 9 op een troon en overweegt zorgvuldig de twee opties die Minerva en Mars hem laten zien. Mars toont een triomfwagen met de Overwinning en de Glorie, terwijl de achthoeken naast de diptiek verwijzen naar de Devolutieoorlog om de beslissing de Verenigde Provinciën de oorlog te verklaren te legitimeren.

De voorbereidingen voor de komende oorlog vormen het onderwerp van het volgende tafereel, waar de koning staand bevelen geeft (5). Neptunus brengt schepen, en Mars troepen, terwijl Minerva de helm van de koning boven zijn hoofd houdt. Op de achtergrond wordt gewerkt aan vestingsteden en het bouwen van schepen, en Vulcanus levert door hem gesmede wapens af. Een grote kaart van Nederland is te zien in het schilderij gewijd aan de aanvalsplannen zelf. Lodewijk houdt een krijgsraad en wijst als opperbevelhebber (te herkennen aan

9 "Résolution prise de faire la guerre aux Hollandois, 1671". Een andere versie van de huidige inscriptie gebruikt het woord "te straffen", zie Piganiol de la Force, Nouvelle description, Parijs, 1764, deel I, p. 122. 
de staf) de plaatsen in het Rijngebied aan die ingenomen moeten worden om zich toegang tot de Republiek te verschaffen. In de hemel boven hem geven een aantal godheden en allegorieën, waaronder Minerva, de Glorie en Mars, goede raad. Aan weerszijden van de koning luisteren de opperbevelhebbers van de Franse legers, waarvan het kampement op de achtergrond te zien is, aandachtig toe.

De eerste oorlogsdaden vatten kort en bondig de visie van de Franse koning samen: de oorlogskoning snelt onstuitbaar voort in zijn triomfwagen. Hij heeft de bliksems van Jupiter in zijn hand en wordt vergezeld door Hercules en Minerva, Roem en Glorie. De titel Oversteek van de Rijn in het bijzin van de vijand, 1672 (2) en de inscriptie "Toluys" (Tolhuis, bij Lobith) op een vaandel maken duidelijk dat het gaat om de inval van de Nederlandse Republiek, op 12 juni 1672. De Rijn vormde eeuwenlang de noordgrens van het Romeinse rijk, en symbolisch gaat Lodewijk de Grote verder dan de keizers uit de oudheid door de limes over te steken, en nog wel zonder noemenswaardige tegenstand.

Het begin van de oorlog is ruim vertegenwoordigd, want het tafereel boven de ingang van de Grote Galerij betreft eveneens het jaar 1672. Volgens de logica van een voortgang van de Oorlogssalon naar de Vrede, is dit schilderij symbolisch het begin van de vertelling. Het gaat om de Alliantie van Duitsland en Spanje met Holland, 1672 (1). Het is symmetrisch geplaatst tegenover het eind van de cyclus, boven de ingang van de Vredessalon. Aldaar heet het dat "Holland de vrede accepteert en zich losmaakt van Duitsland en Spanje, 1678" (12). Hier vinden we dezelfde allegorische figuren als in het centrum van de Spiegelzaal, het Heilige Roomse Rijk, Spanje en de Nederlandse Republiek. De atmosfeer is echter totaal anders, want de drie personages geven elkaar in een tumultueuze en paniekerige sfeer de hand. Door de plaatsing aan het begin van de cyclus, lijkt de Alliantie tussen de drie buurlanden van Frankrijk de legitieme reden te zijn voor de oorlog. Chronologisch is dit echter niet het geval, want het verbond (dat formeel vier partijen telt, en niet slechts drie) komt pas in augustus 1673 tot stand, dat wil zeggen ruim na de Franse inval en als reactie hierop. Deze manier van afbeelden maakt bovendien wellicht de verwarring mogelijk met de Triple Alliantie van 1668, en legitimeert zo de oorlog als wraak voor de afgedwongen Vrede van Aken. ${ }^{10}$ In plaats van verheven godheden zijn hier Angst, Schrik, Vrees en Jaloezie de raadgevers van de afgunstige buurlanden.

Verschillende personificaties van de Glorie en Overwinningen brengen dit schilderij in verband met de panelen van het plafond. Een van de allegorische figuren draagt een vaandel, met het Latijnse aforisme veni, vidi, vici, dat meteen de toon zet en Lodewijk de Grote vergelijkt met Julius Cesar.

${ }^{10}$ In zijn Dusevel (1838: 40), doet Lodewijk XIV de Quadruple Alliantie af als een "zogenaamd verdrag" (prétendu traité). Lotharingen maakt deel uit van het Heilige Roomse Rijk, hetgeen het mogelijk maakt alleen dit keizerrijk af te beelden als opponent van Frankrijk. 
Op een subtiele manier benadrukt het iconografische programma het begin van de oorlog, toen de Franse successen talrijk waren en de overwinning onoverkomelijk leek. Zes schilderijen beslaan de eerste jaren: een voor 1671, maar liefst vier voor 1672 en een laatste voor 1673, met de inname van Maastricht (3). De Franse ontruiming van de Nederlandse Republiek, het keren van het tij en het toenemende politieke isolement van Lodewijk XIV worden verzwegen door nadrukkelijk de overwinningen onder de aandacht te brengen. De Europese fase van de oorlog (1674-1678), die zich geheel buiten de Republiek afspeelt, vormt het onderwerp van slechts vier schilderijen.

De meest concrete terreinwinst geboekt door Frankrijk bij de Vrede van Nijmegen is de annexatie van de Franche-Comté. De verovering van dit Spaanse gebied in 1674, wordt in het drukste tafereel van het hele plafond getoond. De Zonnekoning staat aan de voet van een berg, die de citadel van Besançon symboliseert en die wordt verdedigd door de Spaanse leeuw en de Duitse adelaar. De rots wordt bestormd door Hercules en Minerva, terwijl Mars al eerder veroverde steden aan de voeten van de koning legt. Het grote tumult verwijst naar de moeilijkheden van deze campagne, die bij het hele hof genoeglijk bekend waren en niet verdoezeld konden worden. De onweerstaanbare kracht van Lodewijk XIV wordt hier symbolisch duidelijk gemaakt. Dat gaat ten koste van een contradictie met een andere afbeelding in de Galerij. In een van de centrale achthoekige medaillons, gewijd aan de Vrede van Aken die een einde maakte aan de Devolutieoorlog (achthoeken $\mathrm{C}$ en D), wordt de Franche-Comté afgebeeld als een ontroostbare vrouw. Ze maakt zich hier met moeite en verdriet los van Frankrijk, terwijl de verovering tussen februari en mei 1674 (gememoreerd door de zodiakale symbolen) toch niets weg had van een zoete hereniging. Een van de beschrijvingen van de Galerij gebruikt de term "onderworpen", in plaats van "veroverd", en dat doet wellicht meer recht aan de werkelijkheid. ${ }^{11}$

Het einde van de oorlog is het onderwerp van de laatste diptiek en het halfronde schilderij boven de uitgang van de Galerij. Op het plafond wordt met twee onderling verbonden scènes het beleg van Gent (maart 1678) aangeduid als een groot succes voor Frankrijk en een reden voor het sluiten van de vrede van Nijmegen (augustus-september 1678). Het eerste deel van het schilderij toont de Verovering van de stad en de citadel van Gent in zes dagen, 1678 (10). De Zonnekoning neemt hier Jupiteriaanse vormen aan, en stormt door de hemel, gedragen door de adelaar van Jupiter en met diens bliksemstralen in de geheven hand, af op de verraste allegorieën van Gent en Vlaanderen. Het andere gedeelte van het schilderij geeft de effecten weer die deze bliksemcampagne op Spanje heeft. De

11 Piganiol de la Force, Nouvelle description, Parijs, 1764, deel I, p. 129. De oorspronkelijke titel van François Charpentier, zoals gepubliceerd in de Mercure galant in januari 1685, luidde "La Franche Comté soumise pour la seconde fois avec une promptitude extraordinaire, malgré l'opposition des Saisons, fait repentir l'Espagne, mais trop tard, de son engagement contre la France". 
Roem bazuint de successen van Lodewijk XIV uit en verbijstert de figuren van de Politiek, Raad en Voorzienigheid, die verschrikt opkijken en verblind staren naar het intense licht dat uitgaat van de Zonnekoning. De titel Maatregelen van de Spanjaarden gebroken door de verovering van Gent (11) geeft een idee van de radeloosheid die heerst.

De cyclus komt ten einde met het beschilderde gewelf, waar Holland de vrede accepteert en zich losmaakt van Duitsland en Spanje, 1678 (12). Le Brun gebruikt hier dezelfde compositie als voor de weergave van de ijdele trots van de buurlanden van Frankrijk in het centrum, maar ook als in de scène die symmetrisch boven de ingang van de Galerij is geplaatst. Net als daar is de sfeer paniekerig. Van een alliantie is geen sprake meer en zowel het Heilige Roomse Rijk als de Nederlandse Republiek heffen hun handen ten hemel. De heraldische leeuw van Spanje ligt angstig op zijn rug, met de staart tussen de benen. De titel insinueert dat de Republiek de alliantie verlaat en Spanje alleen achterlaat. In de praktijk was dit niet het geval. Er is weliswaar sprake van een aparte vrede die op 10 augustus te Nijmegen tot stand komt tussen Frankrijk en de Verenigde Nederlanden, maar stadhouder Willem III is dan nog te velde in de Spaanse Nederlanden en dwingt met de veldslag bij Mons (14-15 augustus) het Franse leger ertoe het beleg van die strategische vesting op te breken. Op 17 september komt dan ook, eveneens te Nijmegen, de vrede tussen Frankrijk en Spanje tot stand.

\section{De verheerlijking van de Zonnekoning}

Volgens het officiële relaas, met verve vertolkt in de grandioze Spiegelzaal, eindigt voor de vijanden van Frankrijk de oorlog zoals die begonnen was, in een atmosfeer van afgunst, nijd en paniek. De vrede die gul door Frankrijk wordt aangeboden, wordt in chaos en verwarring aanvaard en slechts omdat er geen ander alternatief is. Maar waar het hier in essentie om gaat is niet de historische juistheid van de verhaalde feiten, maar het gebruik van de Frans-Nederlandse oorlog als instrument van de verheerlijking van Lodewijk XIV. De werkelijkheid is hier ondergeschikt aan de vereisten van een hagiografisch programma.

De Franse koning wordt in Versailles op twee manieren geprezen. Zijn persoonlijke kwaliteiten, en met name die van oorlogsleider, worden breed uitgemeten; daarnaast worden de slechte eigenschappen van zijn vijanden gebruikt als een waar spiegelbeeld van de koninklijke grootsheid. Vanwege de aard van haar politieke stelsel, is de Republiek der Verenigde Nederlanden bij uitstek geschikt om te dienen als tegenvoorbeeld. In het monarchistische denkbeeld fungeert de Republiek als antithese van de koninklijke ideologie. Het monarchistische element van de Republiek, vertegenwoordigd door de stadhouder, wordt nadrukke- 
lijk verzwegen. Prins Willem III, de voornaamste opponent van de Zonnekoning, is dan ook pertinent afwezig van de taferelen.

De eigenschappen van Lodewijk XIV worden methodisch door Le Brun en zijn atelier duidelijk gemaakt, door middel van een paar kunstgrepen. In alle schilderijen waar de koning het belangrijkste onderwerp is, wordt hij in het centrum van de compositie geplaatst. Door clair-obscur-effecten - die dankzij de restauratie van 2004-2007 in volle glorie hersteld zijn - toe te passen, staat de Zonnekoning bovendien altijd in het licht. Deze centrale positie komt overeen met de inzichten van Paul Pellisson (1624-1693), een van de drijvende krachten achter de koninklijke propaganda. ${ }^{12}$ Dit is, bijvoorbeeld, duidelijk het geval in het tafereel in het centrum van de Galerij, waar Lodewijk het lot van Frankrijk in handen neemt (6). De koning bevindt zich in het centrum, badend in het licht. De regalia (troon, mantel, roer) zijn goed zichtbaar en de rijke kleding laat er geen twijfel over bestaan dat het hier om een edel en belangrijk figuur gaat. De belichting en de gouden gloed van zijn kleding leggen een verband met zijn symbool, de zon. De rustige, beheerste houding te midden van een geanimeerde omgeving toont de leiderskwaliteiten van de koning, die op een natuurlijke manier bevelen geeft aan de personages die hem omringen.

Alle andere afbeeldingen van de koning, die zeven keer voorkomt in de cyclus, hanteren dezelfde codes. Op deze manier is de koning eenvoudig te identificeren. Zijn attributen variëren naar gelang de omstandigheden. Zo heeft hij wanneer het om oorlogshandelingen gaat het uiterlijk van een legeraanvoerder uit de oudheid, of welhaast een godheid in het geval van de belegering van Gent. Om de moed van de koning te onderstrepen, draagt hij geen helm, terwijl Mars of Minerva er wel mee getooid zijn. Lodewijk XIV was inderdaad aanwezig tijdens de eerste campagnes van de Frans-Nederlandse oorlog, ook al was zijn vader Lodewijk XIII wellicht de laatste echte koninklijke legerleider in de middeleeuwse traditie.

Ook de omgeving van de koning dient ertoe zijn kwaliteiten en zijn morele superioriteit te onderstrepen. Ondanks de keus van een historisch onderwerp, bevindt de Zonnekoning zich te midden van godheden en allegorieën. Als enige sterveling tussen de mythologische figuren, staat hij op gelijke voet met hen. Op deze manier kan de koning vergoddelijkt worden zonder de katholieke kerk voor het hoofd te stoten, en alvast een voorschot te nemen op de onsterfelijkheid in de geschiedschrijving die de koning door zijn daden wenst te verkrijgen. In sommige gevallen, zoals bij het nemen van de beslissing over het verklaren van de

12 De historiograaf van Lodewijk XIV Paul Pellisson schrijft rond 1670 aan Colbert: "Entre tous les caractères, celui de Sa Majesté doit éclater. Il faut louer le Roy partout, mais pour ainsi dire sans louange, par un récit de tout ce qu'on lui a vu faire, dire et penser, qui paraisse désintéressé, mais qui soit vif, piquant, et soutenu, évitant dans les expressions tout ce qui tourne vers le panégyrique" (Pellisson-Fontaine 1735, 2: 323-328, geciteerd door Marin 1981: 47). 
oorlog, krijgt de Zonnekoning raad van de godheden (9). Desondanks neemt hij zijn beslissing uiteindelijk alleen, en is hij aldus gelijkwaardig aan zijn goddelijke raadgevers. Minerva, die de nadelen van de oorlog uiteen zet, neemt niettemin volop aan de strijd deel nadat Lodewijk XIV daartoe besloten heeft, en toont zich derhalve gehoorzaam aan de Zonnekoning.

In slechts één enkel schilderij komen andere menselijke figuren voor. Het gaat om de scène waar Lodewijk XIV zijn bevelen geeft aan het begin van de oorlog (4). De compositie weerspiegelt een duidelijke hiërarchie. Ook hier is de koning in het centrum geplaatst, op het hoogste niveau van een podium met drie treden. Zijn broer, Filips van Orléans (elders geëerd met een inscriptie verwijzend naar de door hem in 1677 gewonnen slag van Cassel) staat tegenover hem. De veldheer Lodewijk II van Bourbon-Condé (de Grote Condé, 16211686), ook een prins van koninklijk bloed, staat naast de hertog van Orléans. Hij heeft een voet op het podium, en een op de lagere trede. Aan de overzijde staat de tijdens de oorlog gesneuvelde Hendrik van Turenne (1611-1675), met beide voeten op de lagere trede. Als buitenlandse prins van een ander geslacht staat deze maarschalk lager dan de leden van de Franse koninklijke familie. Deze hiërarchie wordt nog eens onderstreept door de blik van de Zonnekoning, die gericht is op de andere Bourbons en niet op Turenne. Lodewijk XIV, elders gelijk aan de godheden, verschijnt in dit schilderij als de onbetwiste en natuurlijke leider in de menselijke maatschappij. Hij is het hoofd van het sociale lichaam en zijn bevelen worden opgevolgd - zelfs door voormalige Frondeurs! - volgens een hiërarchie die aan precieze regels voldoet.

\subsection{De ideale monarch als overwinnaar van de Republiek}

Lodewijk XIV wordt in Versailles systematisch afgebeeld met een royale allure. Maar zijn intrinsieke kwaliteiten krijgen nog meer reliëf door ze in perspectief te plaatsen. Hiertoe dient de vergelijking met de vijanden van de Franse koning, en met name met de Republiek der Verenigde Nederlanden. De cyclus presenteert daarom de Frans-Nederlandse oorlog als een overwinning van de koning op een burgerlijke Republiek. Lodewijk XIV fungeert als belichaming van de ideale monarchie, en zijn succes als blijk van de superioriteit van dit politieke stelsel. De Republiek dient hier als negatief spiegelbeeld van de absolute monarchie.

De Nederlanden zijn daarom alom aanwezig en maken hun entree in het verhaal in de centrale diptiek. De personificatie van de Republiek is er, vol trots, te zien naast die van de bondgenoten, het Heilige Roomse Rijk en Spanje. Le Brun heeft de drie machten in een driehoekige compositie geplaatst, met een duidelijke onderlinge hiërarchie. Ze zijn gerangschikt volgens de 'natuurlijke' orde: het keizerrijk is in het centrum gezeteld, op het hoogste punt van de driehoek. Iets lager bevindt zich het koninkrijk Spanje. Helemaal onderaan, en gezeten op 
balen met handelswaar, zit de Republiek. Ze draagt een diadeem dat rivaliseert met de kronen van de twee monarchieën, en de rijk borduurde mantel verbergt de burgerlijke kleding die eronder gedragen wordt. Het burgerlijke, en dus niet edele, karakter wordt onderstreept door de symbolen van de handel. Ze houdt Thetis, die de rijkdommen van de zee voorstelt, vast aan een ketting. De nimf zit er gelaten bij, in tegenstelling tot de godheden die de Zonnekoning uit vrije wil omringen en actief bijstaan.

De verwaandheid van de Republiek, die zo brutaal is zich de gelijke van de monarchieën te denken, is het centrale leidmotief van de cyclus. In een memorandum over de campagne van 1672 wijt Lodewijk XIV de oorlog aan "de ondankbaarheid, de onwetendheid en onverdraaglijke ijdelheid van de Hollanders". ${ }^{13}$ De inferioriteit van de Republiek wordt duidelijk gemaakt door haar het laagst te plaatsen in het schilderij. Dit wordt nog eens benadrukt door de twee andere machten, die zich tot elkaar wenden, en de Republiek geen blik gunnen. Le Brun maakt een en ander nog eens overduidelijk door het keizerrijk en Spanje op een wolk te plaatsen, en de Nederlanden heel prozaïsch op de grond, bezaait met handelswaar.

Een dergelijke compositie is ook gekozen voor de twee schilderijen boven de in- en uitgang van de Galerij, die het begin en het einde van het verhaal aangeven. Het tumult in deze schilderij staat in schril contrast met de arrogante rust die uitgaat van het tafereel van het centrum van de Spiegelzaal. De angstige atmosfeer en de aanwezigheid van allerlei negatieve allegorieën zoals de Jaloezie, de Woede en de Angst, is diametraal tegengesteld aan de olympische rust en zelfbeheersing die uitgaan van Lodewijk XIV.

Tot een directe confrontatie tussen de figuren van de koning en van de Republiek komt het in de weergave van het begin van de oorlog, en met name de oversteek van de Rijn (2, afbeelding 5) en de inname van Maastricht (3). De oversteek van de Rijn staat hier voor alle Franse overwinningen. ${ }^{14}$ Opnieuw is er sprake van een hiërarchisch verschil. De koning raast in zijn strijdwagen door het schilderij en zijn paarden vertrappelen alles dat in de weg staat. Veel lager in het beeld, en ver van het centrum, staat de allegorie van de Republiek. Ze heeft een angstige blik en haar korte zwaard kan niets betekenen tegen de overweldigende konink-

13 Dusevel 1838: 9: “[on peut] imputer la source et l'origine de la guerre présente qui vient de s'allumer entre la France et les provinces unies, à l'ingratitude, à la méconnaissance et à la vanité insupportable des Hollandois". Cf. p. 16: "[...] les Hollandois entestés, enyvrés de leur grandeur et de leur puissance [...]" en p. 16-17: "De With dont l'esprit étoit fort républiquain [...] vouloit que sa république ne cédât en rien en fierté et en hauteur à la république de Rome [...]". De autobiografische teksten van de Zonnekoning zijn tot stand gekomen met de hulp van Pellisson, en beslaan de jaren van 1661 tot en met 1673. Zie ook Goubert 1994: 321-324.

14 Zie Piganiol de la Force, Nouvelle description, Parijs, 1764, deel I, p. 126: "ce Tableau [de oversteek van de Rijn] ne représente pas seulement le Passage du Rhin, mais encore toutes les Victoires qui le précederent \& qui le suivirent". 
lijke opmars. Allerlei gevallen steden, maar ook de Ambitie van de Republiek liggen al op de grond, overwonnen door Lodewijk XIV. Op haar schild, waarmee ze zich vergeefs tracht te beschermen, staat de tekst van een medaille die de Staten Generaal in 1668 hadden laten slaan, naar aanleiding van de Vrede van Aken. ${ }^{15}$ De arrogantie van de tekst legitimeert, volgens dit narratief, de Frans-Nederlandse oorlog. Aan de andere zijde van dit tweeluik, wordt de inname van Maastricht afgebeeld. Lodewijk XIV wordt er vertegenwoordigd door Mars, en de Republiek neemt de gedaante van Maastricht aan. Mars vliegt met geheven zwaard door de lucht en rukt het schild met het wapen van Maastricht uit haar handen. Opnieuw is de Republiek ondergeschikt, in de vorm van een vallende vrouw die tevergeefs haar zwaard heft. Haar afvallende helm onderstreept nog eens de machteloosheid en haar gezicht verraad wanhoop en radeloosheid.

De andere vijandelijke machten verdienen meer egards, en worden met meer respect weergegeven. Ze worden in de oorlogstaferelen niet door personificaties afgebeeld, maar door hun heraldische embleem (een leeuw en een adelaar), zoals in de scène van de verovering van de Franche-Comté (8). In de laatste diptiek, die betrekking heeft op 1678, wordt de radeloosheid van Spanje na de Franse inname van Gent breed uitgemeten $(10,11)$. Het is echter niet de figuur van de Spaanse monarchie die het moet ontgelden, maar haar raadgevers. De Raad, aan weerszijden bijgestaan door de twee half onderuitgezakte allegorieën van de Politiek en de Voorzienigheid, stellen hier het Spaanse beleid voor. De monarchie zelf blijft derhalve buiten schot. De raadgevers putten hun mening uit de verkeerde bronnen: de Politiek heeft aan haar voeten een boek met de inscriptie "Hist di Machiavelli". De Florentijnse politieke filosoof Niccolò Machiavelli (1469-1527) wordt aldus verantwoordelijk geacht voor de slechte politiek die de raadgevers van de Spaanse koning uitvoeren. De resultaten zijn rondom de ontredderde figuren te zien, met links instortende Hercules-zuilen waarop het motto "Plus Outre" van Karel de Vijfde (1500-1558) te zien is, en rechts in paniek vluchtende soldaten

15 In gouden letters staat er te lezen "assertis legib. emendat. sacr., adju. defens. conci. regibus", afkorting van "assertis legibus, emendatis sacris, adjutis, defensis conciliatis regibus, vindicata marium libertate, pace egregia virtute armorum parta, stabilita orbis europaei quiete, numisma hoc senatus foederati belgii cudi fecit" (ofwel Na de wetten te hebben versterkt, de religie te hebben gereformeerd, de koningen te hulp geschoten, verdedigd en verzoend te hebben, de vrijheid op zee te hebben gewaarborgd en door de wapens een glorieuze vrede bereikt te hebben en de rust in Europa te hebben verzekerd, hebben de Staten van de Verenigde Provinciën der Nederlanden deze medaille laten slaan). De medaille staat afgebeeld in Bizot 1688, I: 266 (en in dezelfde titel, uitgeven te Parijs in 1687). Voltaire noemt deze medaille in zijn Siècle de Louis XIV als een van de voorwendselen voor de oorlog. In zijn Mémoire, (Dusevel 1838: 11-12), schrijft Lodewijk XIV naar aanleiding van deze episode: "J'avoue que leur insolence me piqua au vif et que je fust prest, au risque de ce qui pourroit arriver de mes conquestes aux pays bas espagnols, de tourner toutes mes forces contre cette altière et ingrate nation $[\ldots] "$ ". 


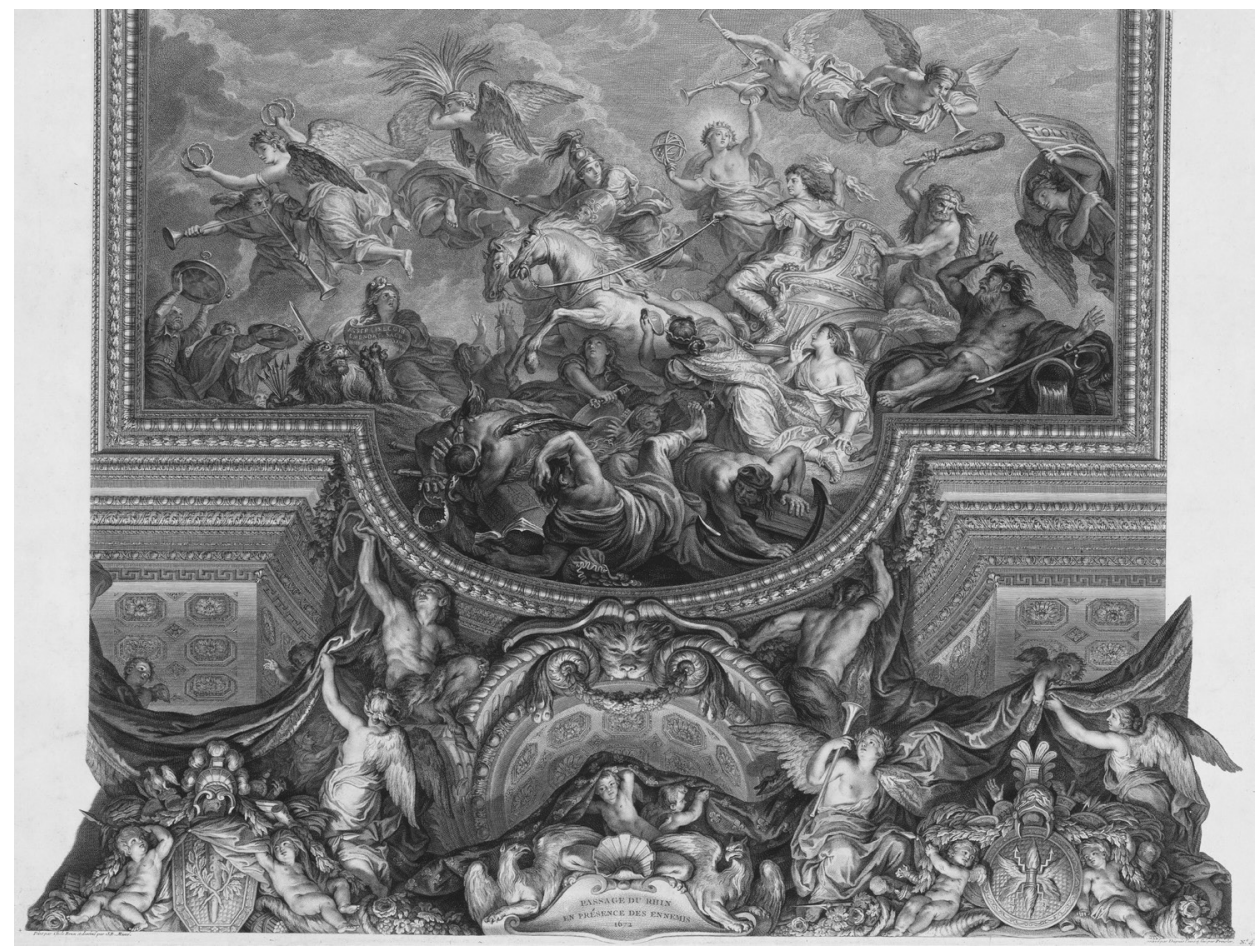

Afbeelding 5. De oversteek van de Rijn in de aanwezigheid van de vijand, 1672 (compositie 2). Achttiende-eeuwse gravure van Charles Dupuis, naar Jean-Baptiste Massé; Rijksmuseum, Amsterdam; bron: Rijksmuseum, Amsterdam (RP-P-OB-73.245)

Het eens zo glorierijke domein van keizer Karel is aldus teloor gegaan, en de Europese preëminentie verloren aan Frankrijk.

Het verschil met de manier waarop de Republiek gezien wordt in de koninklijke denkwereld is fundamenteel. Het is niet de essentie zelf van het politieke stelsel dat slecht is, maar de - overigens hier niet goddelijke - raadlieden die verblind zijn. Door de raadgevers af te beelden, bespaart Lodewijk XIV de Spaanse monarchie een vernederende voorstelling. De aversie die de Zonnekoning heeft voor de 'onbeschaamde' Republiek (Dusevel 1838: 11, 12) verklaart deze iconografische behandeling. In het laatste schilderij van de Spiegelzaal, waar de Alliantie uiteenvalt, wordt de ware aard van de Republiek getoond (12, afbeelding 6). De compositie is vrijwel hetzelfde als die van het tafereel aan het begin van de cyclus. Maar de schijn bedriegt niet meer: de rijke mantel verhult de burgerlijke, of zelfs plebejische kleding niet langer, de diadeem is afgevallen, en de haren van de allegorie zijn zelfs losgeraakt. Dit was in die tijd het summum van vulgariteit voor een volwassen vrouw, en ook de vluchtende houding van de Republiek, die blootsvoets wegrent en haar handen in paniek ter hemel heft, laat de ware aard van de Republiek voluit zien. 


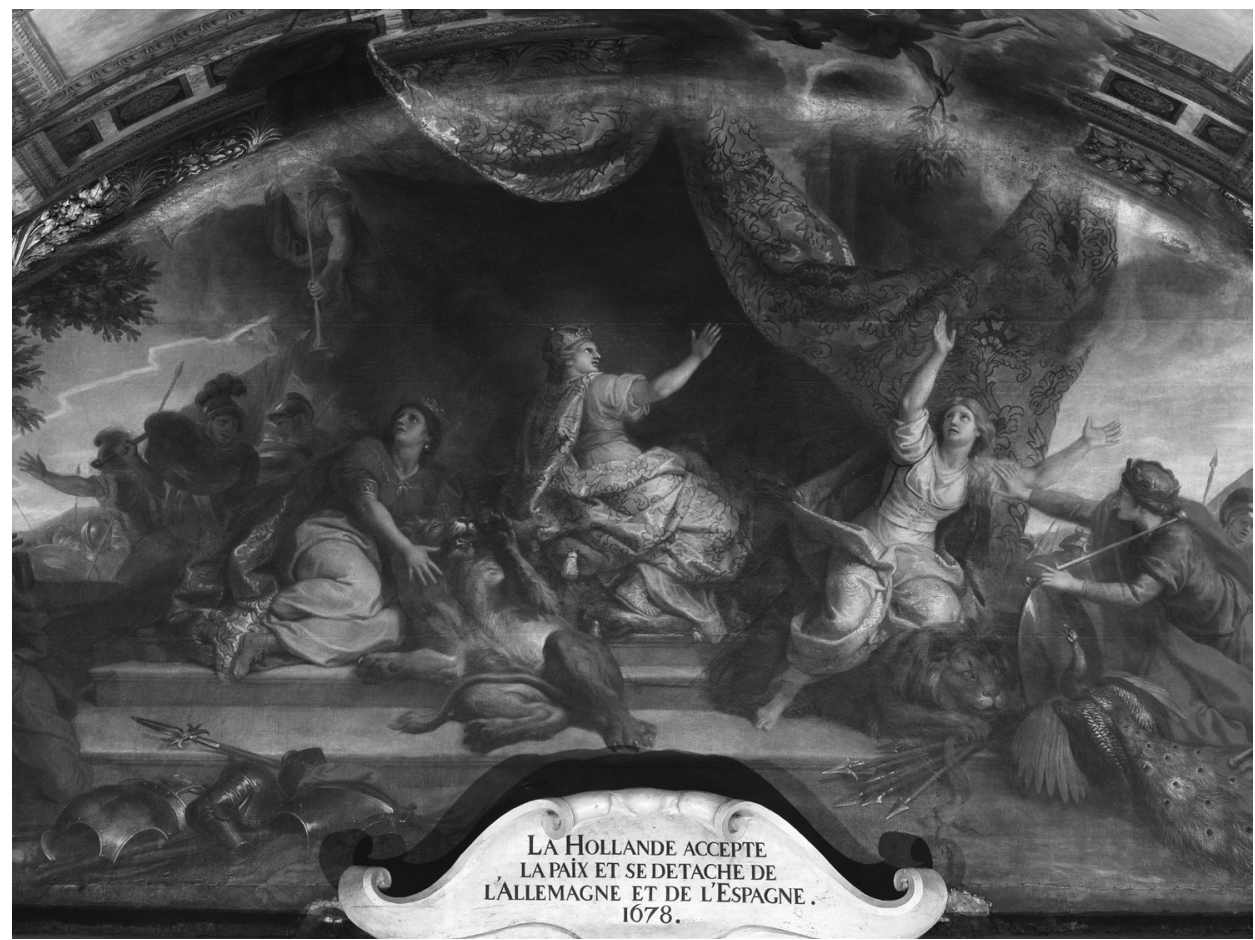

Afbeelding 6. Holland accepteert de vrede en maakt zich los van Duitsland en Spanje, 1678 (compositie 12); bron: Cliché (C) RMN-Grand Palais (Château de Versailles) / René-Gabriel Ojéda / Franck Raux / montage Dominique Couto

Vanwege haar intrinsieke zwakte is de Republiek gedoemd om de wil van Frankrijk opgelegd te krijgen. De houding ten opzichte van de oorlog en de vrede wordt nog eens onderstreept door de schilderijen in de Salons van de Oorlog respectievelijk de Vrede. In de Salon van de Oorlog is de Republiek op een van de halfronde schilderijen boven de ramen afgebeeld als een geharnaste maagd die zich, half vallend, tevergeefs probeert te beschermen tegen de bliksems die door Frankrijk, afgebeeld op de centrale koepel, geworpen worden. Haar heraldische leeuw zoekt eveneens dekking, en heeft nog maar drie pijlen in zijn klauwen, als verwijzing naar de Franse bezetting van vier van de zeven provinciën van het land in het begin van de oorlog. ${ }^{16}$

16 Ook hier is de voorstelling overdreven gunstig voor Lodewijks Frankrijk. Tussen de zomer 1672 en eind 1673 bezetten de troepen van de Franse coalitie de drie provincies Overijssel, Gelderland en Utrecht, en delen van de Generaliteitslanden (met name de Meierij van Den Bosch), en vanaf juni 1673 eveneens het condominium Maastricht. Drenthe en delen van Groningen en Friesland werden slechts tot de Nederlandse herovering van Coevorden in december 1672 geteisterd door Münsterse legers. Bovendien was na 1674 alleen de stad Maastricht nog in handen van de Fransen. Ten tijde van het sluiten van de vrede in 1678 is daarom van de restitutie van provincies aan de Republiek überhaupt geen sprake. 
Aan de overzijde van de Spiegelzaal, in de Salon van de Vrede, wordt hetzelfde schema aangehouden. Ditmaal deelt Frankrijk vanaf het centrale schilderij lauriertakken uit aan de drie voormalige vijanden. De Republiek ontvangt deze dankbaar, evenals de pijlen die de gerestitueerde provincies symboliseren. Haar goudkleurige mantel laat opnieuw eenvoudiger kleren zien, maar het haar is weer keurig opgestoken. Sober geklede en geknielde burgers vouwen de handen dankbaar samen, en op de achtergrond zijn matrozen in de weer om de schepen op orde te brengen. Dit beeld is weer in contrast met de meer feestelijke manier waarop in Spanje (vuurwerk en muziek) en Duitsland (muziek en drank) de vrede ontvangen wordt. Het vormt een minder negatieve afsluiting van een cyclus waarin de Republiek verder stelselmatig wordt gebruikt als negatief spiegelbeeld van de ideale monarchie, zoals de Zonnekoning die belichaamt.

\section{Conclusie: de Republiek als negatief spiegelbeeld van de ideale monarchie}

Vanaf het begin van de persoonlijke regering van Lodewijk XIV wordt er ernst gemaakt met de koninklijke hagiografie. Versailles is er het meest sprekende voorbeeld van, en het hart van het gebouw, de Spiegelzaal, draagt een uitermate politieke boodschap uit. In tegenstelling tot wat gebruikelijk was, is de iconografische cyclus die de immense zaal versiert niet alleen mythologisch of allegorisch, maar historisch van aard. Het is zelfs de zeer recente geschiedenis die is afgebeeld, en Lodewijk XIV is alom zichtbaar.

Het onderwerp dat dient ter verheerlijking van de Zonnekoning, is de Frans-Nederlandse oorlog. Lodewijk XIV wordt vereeuwigd als een oorlogskoning, omgeven door mythologische godheden en allegorieën. Hij personifieert aldus de ideale monarchie. De Verenigde Nederlanden dienen als tegenvoorbeeld. De goede eigenschappen van de Franse koning worden nog versterkt door de vergelijking met een intrinsiek slecht politiek stelsel, de 'verwaande' Republiek. De Nederlanden worden op deze manier geïnstrumentaliseerd voor het uitdrukken van het monarchistische credo. Er zijn talrijke voorbeelden van dit procedé, zoals de triomfbogen Saint-Denis en Saint-Martin in Parijs, maar ook grote aantallen medailles waarin de Nederlandse Republiek wordt gebruikt als negatief spiegelbeeld van het Frankrijk van koning Lodewijk de Grote.

Allicht is er een groot verschil tussen uitbeelding van het historische onderwerp en het geschiedkundige verleden. De koninklijke voorstelling van de zaken probeert altijd plausibel over te komen, maar schroomt niet om een loopje te nemen met de chronologie of de exactheid. De talrijke verwijzingen naar de Nederlanden in het hart van de royale residentie geven enerzijds het grote belang aan van het land in het zeventiende-eeuwse Europa, en anderzijds de ware 
obsessie van Lodewijk XIV om dit politieke stelsel op zijn plaats te zetten. Als heroïsche koning kwijt hij zich van deze taak door de Frans-Nederlandse oorlog te winnen. Althans, volgens de voorstelling die er hier ten toon wordt gespreid.

De nadruk die gelegd wordt op de Frans-Nederlandse oorlog dient een tweeledig doel. Betreffende de binnenlandse politiek is het een behendige manier om de persoonlijke daden van de Zonnekoning onder de aandacht te brengen. Zijn successen wissen de sporen van de zwakte van de monarchie ten tijde van de Fronde uit, en ensceneren een onoverwinnelijke koning als belichaming van een ideale monarchie. Daarnaast legitimeren de ten toon gespreide successen de radicale koersverandering van de Franse buitenlandse politiek. Gedurende vrijwel een eeuw waren Frankrijk en de Nederlanden bondgenoten in de strijd tegen het toen dominante Spanje. Nu Frankrijk de preëminentie van Spanje op het Europese toneel overneemt, is er sprake van een ware renversement des alliances en dient zich een nieuwe fase aan in de Europese geschiedenis.

Het is, ten slotte, opvallend dat dit discours uitsluitend politiek is getint. Het overwinnen van de Republiek komt, in de ogen van de Zonnekoning, overeen met het herstellen van de natuurlijke orde. In de Frans-Nederlandse oorlog, en de weergave ervan in Versailles, speelt religie geen rol. De calvinistische Republiek wordt louter inferieur geacht vanwege de politieke aard. Tijdens de Franse bezetting van grote delen van de Nederlanden, werd de protestantse eredienst dan ook niet verboden. Door de katholieke kerk eveneens weer toe te staan in de openbare ruimte van de bezette gebieden, werd in feite een vrijheid van godsdienst toegestaan volgens het model van het Edict van Nantes. Dat stond paradoxaal in Frankrijk zelf onder toenemende druk.

In de Salon van de Vrede is een schilderij gewijd aan "het christelijke Europa in vrede", waarin de allegorie van Europa triomfantelijk in het midden zit, omringd door Vroomheid en Justitie. De calvinistische Republiek is symbolisch inbegrepen in dit tafereel en wordt niet verworpen vanwege de protestantse aard, maar omwille van een politiek geschil. Het Franse discours verandert in dit opzicht sterk na de herroeping van het Edict van Nantes, in oktober 1685, toen de verf van de Spiegelzaal nog amper droog was. Lodewijk XIV wordt hierna in de Franse propaganda in woord en beeld opgevoerd als een katholieke koning die de ketterij vertrapt. Wellicht heeft de Franse koning juist met deze onverzoenlijke daad heel Europa tegen zich in het harnas gejaagd, ironisch genoeg onder de leiding van stadhouder-koning Willem III die ten faveure van de Frans-Nederlandse oorlog de macht kon grijpen.

\section{Bibliografie}

Allain, Thierry, \& Andreas Nijenhuis-Bescher, Romain Thomas (2019): Les Provinces-Unies à l'époque moderne. De la Révolte à la République batave. Parijs: Armand Colin (= Collection U). 
Apostolidès, Jean-Marie (1981): Le roi-machine, spectacle et politique au temps de Louis XIV. Parijs: Minuit.

Beller, Manfred, \& Joep Leerssen (red.) (2007): Imagology: The Cultural Construction and Literary Representation of National Characters. Amsterdam: Amsterdam University Press.

Bizot, Pierre (1688): Histoire métallique de la République de Hollande. Amsterdam: Pierre Mortier. Burke, Peter (1992): The Fabrication of Louis XIV. New Haven/Londen: Yale University Press.

Charpentier, François (1684): Traité de la peinture parlante, Explication des tableaux de la Galerie de Versailles. Parijs: Muguet.

Davids, Karel, \& Jan Lucassen (red.) (1995): A Miracle Mirrored. The Dutch Republic in European Perspective. Cambridge: Cambridge University Press.

Dusevel, Hyacinthe (red.) (1838): Mémoire de Louis XIV sur la guerre de 1672. Amiens: Caron-Vitet.

Goubert, Pierre (1994): "Manuscrit inconnu et retrouvé. Les mémoires de Louis XIV pour l'année 1673”. In: Paris et ses campagnes sous l'Ancien Régime. Mélanges Jean Jacquart. Parijs: Publications de la Sorbonne.

Félibien des Avaux, André (1674, 1696): Description sommaire du château de Versailles. Parijs: Desprez.

Forclaz, Bertrand (2014): Catholiques au défi de la Réforme. La coexistence confessionnelle à Utrecht au XVII siècle. Parijs: Honoré Champion.

Frijhoff, Willem, \& Marijke Spies (2004): 1650, Hard-Won Unity. Assen: Van Gorcum (= Dutch Culture in a European Perspective, 1).

Israel, Jonathan (1982): The Dutch Republic and the Hispanic world, 1606-1661. Oxford: Clarendon Press.

Israel, Jonathan (1995): The Dutch Republic: Its Rise, Greatness, and Fall, 1477-1806. Oxford: Clarendon Press.

Leerssen, Joep (1999): Nationaal denken in Europa. Een cultuurhistorische schets. Amsterdam: Amsterdam University Press.

Marin, Louis (1981): Le portrait du roi. Parijs: Minuit.

Massé, Jean-Baptiste (1753): La Grande Galerie de Versailles et les deux Salons qui l'accompagnent, peints par Charles Le Brun premier peintre de Louis XIV, dessinés par Jean-Baptiste Massé. Parijs: Veuve Amaulry.

Nijenhuis, Andreas (2001): "L'instrumentalisation des Provinces-Unies dans l'iconographie de Versailles". XVII siècle 210, 75-98.

Nijenhuis, Andreas (2006): "La Guerre de Hollande (1672-1678) et la glorification de Louis XIV à Versailles". In: Jean Garapon (red.), Armées, guerre et société dans la France du XVII siècle. Tübingen: Gunter Narr Verlag, 293-321.

Nijenhuis, Andreas (2014): “L'Hercule français et le lion batave. La perception réciproque à l'aune des relations franco-néerlandaises aux Temps". Deshima, revue d'histoire globale des pays $d u$ Nord 7:1, 57-74.

Pellisson-Fontaine (1735): Euvres diverses. Parijs: Didot.

Piganiol de la Force (1715): Description des châteaux et parcs de Versailles, de Trianon, et de Marly. Amsterdam: David Mortier.

Piganiol de la Force (1764): Nouvelle description des châteaux et parcs de Versailles et de Marly contenant une explication historique de toutes les Peintures, Tableaux, Statues, Vases \& Ornemens qui s'y voient. Parijs: Etienne-François Savoye (Eerste druk: 1701).

Prak, Maarten (2002): Gouden Eeuw. Het raadsel van de Republiek. Nijmegen: SUN.

Rainssant, Pierre (1686): Explication des tableaux de la Galerie de Versailles. Versailles.

Sabatier, Gérard (1999): Versailles ou la figure du roi. Parijs: Albin Michel.

Schama, Simon (1987): The Embarrassment of Riches: An Interpretation of Dutch Culture in the Golden Age. New York: A.A. Knopf. 